ДЕНИЛЬХАНОВ Асланбек Хаважович - кандидат политических наук, доцент философского факультета и факультета Высшей школы бизнеса Московского государственного университета им. М.В. Ломоносова (119991, Россия, г. Москва, ГСП-1, Ломоносовский пр-кт, 27, корп. 4; aslanbekk@yandex.ru)

\title{
ФИЛОСОФИЯ РЕФОРМ ИМПЕРАТОРА АЛЕКСАНДРА І (ОТ «СИМФОНИИ ВЛАСТЕЙ» К ЛИБЕРАЛЬНЫМ ИДЕЯМ)
}

Аннотация. В статье представлен процесс преобразований, который проходила Россия, - от «симфонии властей», берущей свое начало в юридической традиции Византии, к четко выраженным идеям конституционной монархии. Автор отмечает, что оформились эти идеи в виде нормативных актов только в период правления Александра I как попытка систематического реформирования всего государственного строя и механизма государственной власти. В статье анализируются перипетии проведения реформ, связанные как с социально-политической и экономической ситуацией в Российском государстве, так и с личностью самого императора. Автор делает вывод, что в исследуемый период в России еще не сложилась база для конституционного строя, а сами идеалы, которые пыталась внедрить верховная власть по существующим на тот момент юридическим конструкциям в других странах, можно характеризовать как «романтический либерализм».

Ключевые слова: Александр I, М.М. Сперанский, реформы, либерализм, конституционный строй

Л юбое общество развивается в противоборстве идей. Статус-кво периодически подтачивается новыми идеями, имеющими тенденцию к формированию системной оппозиции к основополагающим властным структурам и принципам государственного управления. Затем либо власть принимает часть новых идей, либо новые идеи меняют власть. Именно эта динамика в развитии представлений о государственном устройстве и приводит к осуществлению корректирующих реформ, иногда - структурных.

Россия, как и все страны мира, многократно проходила этот процесс преобразований, зафиксированный в нормативно-правовых актах в разные исторические периоды [Сергеевич 1883б: 599-612]. Даже самый беглый перечень наиболее известных сборников правовых документов - Русская правда, Судебник Ивана III, Судебник Ивана IV (кстати, именно при этом царе была введена выборность местной власти), - сам факт неоднократного избрания царей на Земских соборах, наличие известных и активных «диссидентов», таких как Андрей Курбский или Григорий Котошихин, свидетельствуют о том, что на Руси, а затем и в Московском княжестве была основательная традиция перманентного политического и хозяйственного развития страны, а также альтернативные взгляды на эти процессы.

Законотворческая деятельность в стране осуществлялась с учетом опыта ближних и дальних соседей, начиная с Византии и заканчивая европейскими странами. При этом все правовые системы, которые брались за образец, адаптировались к конкретным обстоятельствам и потребностям страны на определенном историческом этапе. При всех реформах сохранялся основополагающий принцип государственного устройства - «симфония властей», усвоенный в период раннего ученичества Руси, взятый в юридической традиции Византии, а именно самодержавие, благословляемое Церковью.

Первым государем, нарушившим этот фундаментальный принцип «симфонии властей», был император Петр I. Он резко ограничил права русской Церкви, упразднил патриаршество, заменив его Святейшим правительству- 
ющим синодом. Подчинив Церковь государству, он поставил точку в вековых спорах о приоритете светской или духовной власти. Конечно, можно утверждать, что с правления Петра I в Россию проникают либеральные идеи, которые примерно в это время начинают оформляться в Европе [Костомаров 1992; Ключевский 1991; Вернадский 1924; Анисимов 1989; Богданов 1998; Буганов 1989], и происходит этот процесс на фундаменте зарождающегося гуманизма и поступательной секуляризации общественного сознания. В это время представители высшего сословия России свободно читали и обсуждали труды Ж. Бодена, Т. Гоббса, Г. Гроция и, конечно, Д. Локка. Знание иностранных языков у просвещенной части населения уже было достаточным для усвоения новых европейских идей. Однако оценка времени правления Петра I как этапа становления либерализма в России не является бесспорной. Свой классический труд «История либерализма в России» В.В. Леонтович начинает с 1762 г., т.е. с правления Екатерины II. Но и здесь можно говорить лишь о «вкраплениях» либеральных идей в достаточно устойчивое и косное общественное сознание. При том, что в культурный обиход высших слоев входит обыкновение обсуждать проблемы несовершенства управления и необходимости освобождения мыслящей личности, для возникновения либерального дискурса не доставало, во-первых, критики самодержавия как формы правления (хотя в истории России было достаточно попыток ограничить власть монарха); во-вторых, четко выраженных идей конституционализма и парламентаризма. Эти идеи врываются в пространство общественных отношений лишь в начальный период правления Александра I. На долю этого монарха выпадает одна из самых тяжелых и кровопролитных войн в истории России - война с Наполеоном. Отечественная война 1812 г. оказала огромное воздействие на личность императора, в сущности перевернув его мировоззрение. Емкую характеристику особенностей личности Александра I дал Е.В. Тарле, описывая его поведение в период войны 1812 г.: «Этот человек в своей жизни несколько раз менялся. Наследником он был одним, после убийства Павла другим, перед Аустерлицем - третьим, после Аустерлица - четвертым, после Тильзита - пятым. А еще сколько предстояло перемен в годы Голицына и Аракчеева! И не просто менялось его настроение, его отношение к жизни, проявление его характера. Кто-то из его современников выразился так: Александр, как Будда по индийским сказаниям, проходит всю жизнь через разные преображения, “становления", разные “аватары”, поэтому у него и является всякий раз совсем новое лицо. Нас тут интересует его “преображение” перед войной 1812 года и во время этой войны. Кем он был тогда? Каковы были его стремления? Александр умел держать себя в руках, как ни один из русский царей и как вообще очень редко какой-либо из самодержцев в любой стране» [Тарле 1994: 11-12]. И, тем не менее, «Александр, в панике после фридландского разгрома, решился не только на мир, но и на самую крупную и решительную перемену, вернее, на полный переворот во всей своей политике» [Тарле 1994: 11]. Этот поворот случился потому, что в глазах Александра I была разрушена иллюзия идеальной Европы и совершенной Франции, которая, как ему представлялось, вела все народы Европы к свободе и братству. Для него это были крайне болезненные уроки, потому что подтачивался самый фундамент представлений о мире, который был заложен в раннем детстве особенностями воспитания.

Екатерина II, жестко взявшая в свои руки воспитание не просто внука, но наследника престола, выбрала за основу образец европейского либерального свободомыслия. По странной логике для воспитания наследника самодержавного государства был выбран республиканец, генерал Ф.С. Лагарп, гражданин республиканской Швейцарии, который в ходе Великой французской 
революции изменил написание фамилии, удалив дворянскую частицу de, на практике подтвердив свои демократические принципы. Ф.С. Лагарп учил наследника европейской истории, делая акцент на развитии свободомыслия и идей равенства. «Воспитатель особенно заботится о развитии в своем старшем ученике уважения к достоинству человеческой личности и отвращения ко всему порочному и злому», - так характеризовал задачи воспитания швейцарцем наследника престола историк XIX в. [Глинский 1888: 64]. Ф.С. Лагарп говорил юному Александру, что эра абсолютных монархов миновала и потому идеалом государственного устройства он считает конституционную монархию. Потому просвещенному монарху следует начать свою деятельность с проведения глубоких реформ, главная из которых - принятие конституции. Необходима также отмена крепостного права, что, по мнению умного и опытного Ф.С. Лагарпа, потребует немало мужества, т.к. придется преодолевать жесткое сопротивление дворян. Разумеется, Ф.С. Лагарп не имел достаточного представления о русской истории. Она и не была написана в тот период. «История государства Российского» Н.М. Карамзина начнет публиковаться после 1816 г., а «История Российская» В.Н. Татищева носила скорее публицистический, а не описательный и аналитический характер. Отсутствие написанной истории и авторитетных историков в общественном сознании было равно отсутствию самой истории, нравственному и интеллектуальному небытию страны. Потому необходимо было эту страну строить и учиться самым основам общественного устройства у далеко ушедшей вперед Европы. В этой логике осуществлялось развитие нескольких поколений русских либералов, а затем - интеллигентов. Только после того, как появились многочисленные исторические труды, открылась колоссальная ретроспектива пути, пройденного народом.

«Будучи наследником престола, Александр немного фрондировал против отца. Он говорил, что мечтает дать народу конституцию, устроить его жизнь и удалиться в маленький домик где-нибудь на берегах Рейна» [История России... 1996: 303]. Легкое фрондерство по отношению к нелюбимому царю обеспечило Александру I расположение высшего дворянства. Потому общество искренне приветствовало приход к власти молодого, красивого и либерально настроенного императора. Начало его правления было отмечено всеобщим оптимизмом. Царствование Александра I по праву может считаться эпохой наибольшего расцвета идей либерализма в дворянской среде и толчком для дальнейшего развития либерализма в России. Именно из этого корня, оказавшегося жизнеспособным, выросли впоследствии и принципы, и психология русского либерализма. Потому так важно понять природу этого истока, определить, какой импульс движения был задан в этот период.

В манифесте «O кончине Императора Павла I, и о вступлении на Престол Александра I» от 12 марта 1801 г. декларировался отказ от консервативной политики Павла I. После вступления на престол молодой император постарался опереться на близких по духу людей. Как правило, это были старые придворные сторонники английского конституционализма: канцлер А.Р. Воронцов - англоман (потому для него важен был разрыв отношений с Францией и сближение с Англией), адмиралы Н.С. Мордвинов - поклонник английской политической системы и П.В. Чичагов - известный англофил. На этих опытных политиков и царедворцев большое впечатление произвела французская революция. Они опасались повторения кровавых событий в России и призывали к осторожности при проведении реформ, которые должны были осуществляться в рамках западноевропейского опыта. Но Александр I стремился реализовать проекты максимально быстро и полно. Общество было взбудоражено предчувствием 
перемен, отсюда пушкинское «...дней Александровых прекрасное начало...» ${ }^{\text {. В }}$ первые же дни своего правления император издает следующие указы: 15 марта 1801 г. была объявлена амнистия политическим заключенным (освобождены А.Н. Радищев, А.П. Ермолов) и беглецам, укрывшимся за границей, восстановлены дворянские выборы в губерниях, разрешен ввоз и вывоз различных товаров; 22 марта 1801 г. объявлен свободный въезд в Россию и выезд за ее пределы, весьма ограниченный при Павле I; 31 марта 1801 г. разрешена деятельность типографий и ввоз любых книг из-за границы (в то время это была немыслимая свобода для многих стран Европы, в особенности для наполеоновской Франции); 2 апреля 1801 г. восстановлены екатерининские жалованные грамоты дворянству и городам; в тот же день было уничтожено учреждение политического сыска - Тайная экспедиция (в стране не стало, правда ненадолго, и самой тайной полиции); 27 сентября 1801 г. были запрещены пытки. Но на этом нововведения затормозились. Александр I хотел систематического реформирования всего государственного строя и механизма государственной власти. Для работы над планами реформ он привлек своих ближайших друзей, создав совещательный орган, приватность деятельности которого обеспечивали близкие дружеские отношения всех участников. Кружок единомышленников получил название «Негласный комитет». В него входили молодые, хорошо образованные дворяне, подолгу жившие за границей и пропитанные европейским духом: А.Е. Чарторыйский, В.П. Кочубей, Н.Н. Новосильцев и П.А. Строганов. Были ли эти люди (всего на несколько лет моложе двадцатитрехлетнего Александра) государственно мыслящими людьми? Готовы ли они были к масштабной работе по усовершенствованию управления страной, которой не знали? Их объединяло то, что они видели политический идеал в британской конституционной монархии.

Современный исследователь эпохи Александра I заключает: «Совершенно очевидно, что деятельность “Негласного комитета" была необходима Александру I в интересах выработки государственной политики в 1801-1802 гг. Он обсуждал со своими друзьями проекты важнейших решений по реформе административной системы (статус Сената, образование министерств), крестьянскому вопросу и внешнеполитическим проблемам» [Демкин 2012: 110]. Здесь следует добавить: не изучив конкретные проблемы и нужды, не выявив конкретные недостатки существующей системы своей страны; действуя из благих, но идеальных, романтических побуждений; выстраивая внутреннюю структуру по идеальной модели, усвоенной из опыта других стран, с полным непониманием, а потому и невниманием к логике развития своего государства; желая блага, но не зная путей к нему.

Александр I говорил неоднократно, что в своем правлении во внутренней политике он будет руководствоваться строгой законностью, не допуская произвола. Для этого необходимо было разработать фундаментальные законы. С этой целью и велись преобразовательные опыты первых лет.

Решающую роль в разработке философии реформ сыграл М.М. Сперанский. Выходец из семьи мелкого церковнослужителя, благодаря выдающимся способностям он стал практически вторым человеком в империи. Способности М.М. Сперанского привлекли к себе внимание членов «Негласного комитета», и он очутился в самом узком кругу молодых преобразователей. В его обязанности входило составление части проектов переустройства государства, в частности по реформированию органов управления - министерств. В 1802 г. M.M. Сперанский подготовил несколько собственных политических запи-

\footnotetext{
1 Речь идет о стихотворении А.С. Пушкина «Послание цензору».
} 
сок: «О коренных законах государства», «Размышления о государственном устройстве империи», «О постепенности усовершения общественного», «О силе общественного мнения», «Еще нечто о свободе и рабстве». Здесь были изложены взгляды М.М. Сперанского на состояние государственного аппарата России, а главное - на принципы политического устройства страны. К примеру, в работе «О коренных законах государства» он писал: «...вместо всех пышных разделений свободного народа русского на свободнейшие классы дворянства, купечества и проч. я нахожу в России два состояния: рабы государевы и рабы помещичьи. Первые называются свободными только в отношении ко вторым, действительно же свободных людей в России нет, кроме нищих и философов» [Сперанский 2010: 208]. Широкие обобщения в статьях раннего М.М. Сперанского носили скорее философско-поэтический характер, в них не отражалось понимание сложной и разветвленной структуры российского общества начала XIX в., непростых, требующих реформирования, но на данный момент остающихся фундаментальными имущественных отношений.

Реформаторы не хотели ждать, когда в обществе зародятся новые экономические способы ведения хозяйства, они стимулировали их появление. Так, в феврале 1803 г. вышел знаменитый Указ о вольных хлебопашцах, который готовился при участии М.М. Сперанского. Согласно этому указу помещики получили право давать вольность крепостным, наделяя их землей. За годы царствования Александра I этот указ позволил освободить 37 тыс. чел. Указ вызвал недовольство широкого круга землевладельцев. Воспользовалась им лишь очень малая часть помещиков. Еще большее недовольство, а можно сказать, даже ненависть вызвал разработанный М.М. Сперанским указ «Об экзаменах на чин», который был направлен на стимулирование процесса повышения грамотности и профессионального уровня чиновников. По этому указу чины коллежского асессора и статского советника могли даваться только при предъявлении соискателем чина диплома об университетском образовании. Чиновники преклонного возраста, прослужившие уже не один десяток лет, должны были выдержать экзамены в объеме университетского курса. Этот указ мешал старым чиновникам продолжать службу, и государство лишалось опытных служащих. М.M. Сперанский стремился поднять русское чиновничество на новый уровень, в т.ч. это касалось и уровня бюрократической культуры. Во всяком случае, ему удалось преобразовать деловой язык, сделав его емким и точным, удалив ненужные этикетные формулировки.

В личности М.М. Сперанского странным образом сочеталось воодушевленное стремление к идеалу вопреки существующим обстоятельствам и скрупулезная позитивистская точность добросовестного канцеляриста. В 1808 г. император назначил его своим главным советником и поручил подготовить план государственных преобразований. В рамках этой задачи М.М. Сперанский и его помощники провели большую подготовительную работу по изучению законодательных документов других стран. Осенью 1809 г. план государственных преобразований был готов и обнародован под названием «Введение к уложению государственных законов». Современный исследователь отмечает: «Уже в начале XVIII века назрела потребность в пересмотре законодательства... В XVIII веке появляется новое отношение к праву: если раньше фиксировались нормы обычного права, то теперь делаются попытки создать новые. По этому пути пошли и российские законодатели» [Ружицкая 2011: 6]. Необходима была кодификация разрозненных и разновременных законов, указов и подзаконных актов. «Первая деятельность Сперанского на поприще законодательства носит отпечаток сильного влияния Франции и кодекса Наполеона» [Сергеевич 1883a: 606]. 
Гражданский кодекс, известный как Кодекс Наполеона, впервые изданный в 1804 г., оказал со временем влияние на законодательство многих стран. Во Франции долгие годы работала большая кодификационная комиссия, которая опиралась на систематические материалы, накопленные в XVIII в., т.е. проделала ту работу, которая была возложена на М.М. Сперанского относительно законодательства России (и которую он с успехом проделает несколько лет спустя). Но пока он следовал авторитетному для него, да и для многих людей в России, примеру. Кодекс Наполеона исправлял ситуацию во Франции, потому что «к концу XVIII века правовая ситуация в государстве оставляла желать много лучшего. В стране царил почти полный правовой хаос» [Захватаев 2012: 194]. Но Кодекс был направлен не только на преодоление хаоса, он предлагал и новые экономические отношения в стране, находившейся на пике революционного подъема. Именно этот образец и был выбран М.М. Сперанским. «С первых дней Великой французской революции ее устремления были направлены на разрушение старых, отживших социально-правовых устоев и на построение нового общества. Революционеры буквально грезили идеями общества, основанного на принципах рационального и более совершенного законодательства, на равенстве всех граждан перед законом и на полной свободе их деятельности, которая должна была осуществляться в рамках этого законодательства» [Захватаев 2012: 200-201]. М.М. Сперанский был уверен, что «подобное чудо можно и должно совершить и у нас [в России]. Дело же было и не слишком мудреное. Французский кодекс состоит всего-навсего из 1800 параграфов, и передать их в прекрасных русских фразах можно без большого труда в какойнибудь год» [Корф 1861: 160]. Он и стал основой для реформаторских проектов М.М. Сперанского.

В 1810 г. систематизированные предложения М.М. Сперанского, названные «Введение к уложению государственных законов», рассматривались в Государственном совете, секретарем которого являлся М.М. Сперанский. Эта высокая должность поставила его, по сути, на вторую ступеньку во властной иерархии после императора. К предложенному документу было пристальное внимание, ведь преобразования должны были затронуть все слои русского общества. Реакция на документ была отрицательной. По общему мнению, предложенные М.М. Сперанским реформы подрывали государственные устои России. Это тяжелое обвинение звучало из Твери - из дворца сестры Александра I великой княгини Екатерины Павловны, вокруг которой собрались представители образованного дворянства, московского «старого русского» круга. Консолидированную точку зрения этих людей выразил Н.М. Карамзин, написавший по просьбе великой княгини «Записку о древней и новой России», ставшей своего рода «манифестом русского консерватизма» [Пайпс 2008: 120]. Пафос этой записки состоял в том, чтобы осудить любые попытки ограничения самодержавия. Дело доходило до того, что великий историк отрицал необходимость освобождения крестьян, подводя под эту мысль этические обоснования: «И будут ли земледельцы счастливы, освобожденные от власти господской, но преданные в жертву их собственным порокам, откупщикам и судьям бессовестным? Нет сомнения, что крестьяне благоразумного помещика... счастливее казенных, имея бдительного Попечителя и заступника. Не лучше ли под рукою взять меры для обуздания господ жестоких?» [Карамзин 1914: 82]. Но основная мысль Н.М. Карамзина состояла в том, что внутреннее политическое устроение страны должно логически вытекать из ее исторического опыта. И потому заимствование законодательной базы у французов оскорбительно для России.

М.М. Сперанский, столкнувшийся с волной недовольства результатами своей 
работы, признал ее ошибки. «В отчете 1810 года М.М. Сперанский, сознававший несовершенство своего Уложения, отмечал неподготовленность материалов, недостаток сведущих людей, трудность самой задачи, сравнивал это положение с тем, как обстоит дело во Франции» [Ружицкая 2011: 8]. В марте 1812 г. М.М. Сперанский был отправлен в отставку и выслан из Москвы. План либеральных реформ, предложенный им, был абстрактным, строился на идеальных и несвоевременных схемах.

Неудачи с реформами объясняются не только сложностью подготовительного процесса и концептуальной неразработанностью проекта, приводившего к простому заимствованию перспективной модели развития страны и многочисленной критике, препятствием были и исторические обстоятельства. В 1805 г. начались наполеоновские войны в Европе, и это поглотило все внимание властей. Россия примыкает к антифранцузской коалиции и участвует во всех крупных сражениях на территории Европы, реформы откладываются. Кроме того, Александр I почувствовал, что натолкнулся на мощное сопротивление чиновничества и консерваторов. Эти группы элиты, хотя и не демонстрировали оппозиционность, всячески тормозили дело.

Войны начала XIX в. и участие России почти во всех военных событиях на территории европейских государств определили и внутреннюю политику страны. Все силы напрягались для ведения войны. Для Александра I события в Европе представлялись продолжением внутренней политики, его глубокая вовлеченность в жизнь Европы требовала и действенного соучастия. Война продолжалась далеко за рубежами страны, истощая силы народа. Жесткую оценку этому периоду и политическим решениям императора дал Ф.М. Достоевский: «...Екатерина была гениальна, а Александр - нет» [Достоевский 1982: 82]. Александр I жил с оглядкой на Европу. Все внешнеполитические достижения его правления, и прежде всего победа над Наполеоном, не были использованы в интересах России, считает Ф.М. Достоевский, и война с Наполеоном окончилась в пользу Европы.

К вопросам реформирования России вернулись только после смерти Александра I и вступления на престол Николая I. При этом была принципиально изменена концепция реформ. «С 1700 года законодательство колебалось между двумя видами кодификации: между уложением сводным, как его тогда называли, т.е. между собранием действующих законов без всяких к ним изменений и уложением новым, дополненным и исправленным “из общих начал законоведения” (так определена была, например, задача комиссии 1803 года). 〈...> И только в 1826 году, когда М.М. Сперанский представил императору Николаю Павловичу на выбор одну из этих двух систем, “Государю Императору”, как говорил М.М. Сперанский, “благоугодно было решительно избрать первую, т.е. составить Свод законов “без всяких изменений” » [Винавер 1908: 2-3]. Таким образом, «основные положения Гражданского уложения оказались неприемлемыми для правовой системы тогдашней России. Его идеи впоследствии не были востребованы в ходе кодификационных работ... в царствование Николая I» [Ружицкая 2011: 11].

М.М. Сперанский оставался сторонником конституционного строя, но понял, что в России еще не сложились условия для его введения. Он понял, что необходима огромная работа по изучению страны в ретроспективе, и это так же важно, как изучение современного состояния ее экономики и деловой жизни. В 1827 г. М.М. Сперанский составил «Заметки по организации судебной системы в России» и «Записку о причине убыточности Нерчинских заводов и мерах по улучшению их положения». А затем под его руководством к 1833 г. была завершена работа над 45 томами «Полного собрания законов Российской 
империи» и 15 томами «Свода законов Российской империи». Возникла база для понимания исторической логики юридического развития России.

Александровская эпоха имеет отчетливые временные параметры - с воцарением Николая I атмосфера в стране принципиально меняется. Время Александра I - это время воодушевления, конечно, связанного с патриотическим подъемом, военными победами, заграничными походами, время ожидания благотворных перемен. При этом благо понималось как реализация идеальных схем организации государственного устроения, полученных в результате глубокого знания европейских философских трактатов XVIII в. и связанных с утверждением принципов гуманизма и политической структуры европейских государств. Сложилась иллюзия, что можно воспользоваться готовым опытом, чтобы коренным образом перестроить свое государство на либеральных основаниях.

Александровская эпоха - это и время сурового отрезвления. Есть громадная мемуарная литература, в которой участники походов против Наполеона говорят о своем разочаровании в практической реализации идеалов свободы в Европе. Но сами идеалы, мечта о возможности построения разумного общества по уже существующим у других народов конструкциям (поиск идеала в чужой истории, в чужой культуре, в чужой политической практике) вошли в традицию, которую можно определить как «романтический либерализм». Позднее в Александровской эпохе увидели разнонаправленные полюса общественной мысли, что позволило артикулировать различие позиций западников и славянофилов. «Романтический либерализм» привел к феномену декабризма - восстанию, заведомо обреченному на неудачу, и отзывался в дальнейшем во многих реформаторских схемах все более крепнущего русского либерализма.

Реформы являются неотъемлемым атрибутом жизнедеятельности любого государства. Последовательное реформирование властных структур, системы управления, экономики и социальной сферы позволяет избежать революционных потрясений и улучшить качество жизни граждан, населяющих ту или иную страну. В российской истории немало примеров проведения реформ как превенции революционных настроений в обществе (реформы Ивана Грозного, Петра I, Екатерины II, Александра I, Александра II, реформы середины 80-х гг. прошлого века и др.). Общим для всех этих реформ является то, что они были инициированы верховной властью (или «сверху», как принято это трактовать в исследовательской литературе) и направлены либо на решение уже обострившихся до предела проблем, либо на исправление сложившейся в стране неблагоприятной социально-экономической или политической ситуации.

Разработка реформ предполагает непрерывную аналитическую работу всех политически активных акторов - государственных органов, их должностных лиц, органов местного самоуправления и общественных организаций - с вынесением на широкое обсуждение законопроектов, затрагивающих интересы большинства населения. В конечном итоге, реформирование страны - это воплощение в жизнь нормативно-правовых актов, принимаемых верховной властью. Поэтому важно, чтобы законодатель оперативно реагировал на появляющиеся новые общественные отношения с целью их юридической формализации, не создавал при этом «каучуковые» (или «резиновые») нормы, которые можно трактовать расширительно, либо заведомо невыполнимые законы в силу отсутствия условий и механизмов их реализации. Законы пишутся не для профессионального сообщества (юристов), как это нередко выглядит в результате сложности восприятия действующих норм, а для всех социальных слоев 
населения, которым должны быть понятны правила должного поведения, обязанности и запреты, а это, в свою очередь, означает, что язык права должен быть простым и понятным каждому гражданину. Важно, чтобы человек для законодателя был не только субъектом права, но, согласно Конституции РФ (ст. 2), представлял собой высшую ценность.

Результаты реформ зависят от многих факторов, которые необходимо учитывать в государственном управлении. Остов реформ должны составлять национально-государственная идея, призванная консолидировать общество; рыночная экономика, свободная от притеснений со стороны чиновников и бюрократии; правовая среда, которая направлена на формирование правосознания и правовой культуры как рядовых граждан, так и представителей публичной власти; гражданское общество, которое определяет баланс интересов власти и населения; научные методы, которые необходимы для серьезной аналитической работы и прогнозирования результатов реформ.

Отсутствие концептуального подхода в отношении целей и перспектив развития государства ведет к необходимости перманентного решения правительством злободневных проблем, неоправданным расходам бюджетных средств и, как правило, к деструктивным последствиям. Перманентное обращение к истории страны, истокам различных реформ позволяет извлечь определенные уроки, которые могут явиться основой для модернизации современного российского государства.

\section{Список литературы}

Анисимов Е.В. 1989. Время Петровских реформ. СПб: Лениздат. 496 с.

Богданов А.П. 1998. В тени Великого Петра. М.: Армада. 329 с.

Буганов В.И. 1989. Петр Великий и его время. М.: Наука. 192 с.

Вернадский Г.В. 1924. Очерк истории права Русского Государства ХVIII - ХІХвв. Прага: Пламя. 166 с.

Винавер М.М. 1908. Из области цивилистики. СПб: Типография А.Г. Розена. $344 \mathrm{c}$.

Глинский Б.Б. 1888. Республиканец при русском дворе. - Исторический вестник: историко-литературный журнал. Т. 24. СПб. Октябрь. С. 54-96.

Демкин А.В. 2012. "Дней Александровых прекрасное начало»: Внутренняя политика Александра І в 1801-1805 г2. М.: Кучково поле. 320 с.

Достоевский Ф.М. 1982. Записная тетрадь 1876 года. - Полное собрание сочинений. В 30 т. Л.: Наука. Т. 24. 520 с.

Захватаев В.Н. 2012. Кодекс Наполеона: монография. М.; Берлин: Инфотропик Медиа. 790 с.

История России: С начала XVIII до кониа ХІХ века: учебное пособие для вузов (отв. ред. А.Н. Сахаров). 1996. М.: АСТ. 576 с.

Карамзин Н.М. 1914. Записка о древней и новой России (под ред. В.В. Сиповского). СПб: Типография А.Ф. Дресслера; Издание Графини М.Н. Толстой. 133 с.

Ключевский В.О. 1991. Исторические портреты. М.: Изд-во «Правда». 623 с.

Корф М.А. 1861. Жизнь графа Сперанского. СПб: Изд. Имп. Публ. библ. 283 с.

Костомаров Н.И. 1992. Русская история в жизнеописаниях ее главнейших деятелей. Кн. III. Вып. 6, 7. Репр. воспр. изд. 1873-1888 гг. М.: Книга и бизнес. 780 с.

Пайпс Р. 2008. Русский консерватизм и его критики: исследование политической культуры. М.: Новое издательство. 252 с.

Ружицкая И.В. 2011. «Статьи проекта не совсем соответствуют духу русских законов...»: кодификационная деятельность в царствование Александра I. Вестник Российского университета дружбы народов. Сер. История России. № 1. C. 5-17. 
Сергеевич В.И. 1883а. Лекции и исследования по истории русского права. СПб: Типография и хромолитография А. Траншеля. $998 \mathrm{c.}$

Сергеевич В.И. 1883б. Указная деятельность государей: лекции и исследования по истории русского права. СПб: Типография и хромолитография А. Траншеля. $997 \mathrm{c}$.

Сперанский М.М. 2010. О Коренных законах государства. - Избранное (сост., вступ. ст. и коммент. В.С. Парсамова). М.: РОССПЭН. С. 194-216.

Тарле Е.В. 1994. 1812 год. М.: Пресса. 544 с.

DENIL'KHANOV Aslanbek Khavazhovich, Cand.Sci. (Pol.Sci.), Associate Professor of the Faculty of Philosophy and the Faculty of Higher School of Business, Lomonosov Moscow State University (bld. 4, 27 Lomonosovsky Ave, Moscow, Russia, 119991; aslanbekk@yandex.ru)

\title{
THE PHILOSOPHY OF THE REFORMS OF EMPEROR ALEXANDER I (FROM «SYMPHONY OF AUTHORITIES» TO LIBERAL IDEAS)
}

\begin{abstract}
The article presents the process of transformation that took place in Russia - from the "symphony of authorities", which originates from the legal tradition of Byzantium, to the clearly expressed ideas of the constitutional monarchy. The author notes that these ideas took the form of regulations only during the reign of Alexander I as an attempt of systematic reform of the entire state system and the mechanism of state power. The article analyzes the vicissitudes of the reforms running, associated both with the socio-political and economic situation in the Russian state, and the personality of the Emperor himself. The article concludes that in the studied period, Russia has not yet formed the basis for the constitutional system, and the ideals that the supreme power tried to introduce according to the existing at the time legal structures of the other countries, one can characterize as romantic liberalism.
\end{abstract}

Keywords: Alexander I, M.M. Speransky, reforms, liberalism, constitutional order 